\title{
Identification of Sources and Inheritance of Resistance to Sphaceloma Scab in Cowpea
}

\author{
C. K. Nakawuka, Former Graduate Student, and E. Adipala, Plant Pathologist, Department of Crop Science, Mak- \\ erere University, P.O. Box 7062, Kampala, Uganda
}

\section{ABSTRACT}

Nakawuka, C. K., and Adipala, E. 1997. Identification of sources and inheritance of resistance to Sphaceloma scab in cowpea. Plant Dis. 81:1395-1399.

Resistance in cowpea to Sphaceloma scab was characterized based on foliar and pod infection. Disease severity on cowpea plants was rated on a scale of 1 to 5 , as follows: $1=$ no symptoms, 2 $=$ less than $10 \%$ infection, $3=10$ to $20 \%$ infection, $4=20$ to $50 \%$ infection, and $5=$ more than $50 \%$ infection. Mean severity scores were used to calculate areas under the disease progress curve. Of the 75 cowpea lines evaluated, 10 were resistant, 30 were moderately resistant, and 35 were susceptible based on foliar infection. For pod infection, 24 lines were resistant, 40 were either moderately resistant or susceptible, and 11 were very susceptible. Local lines were less infected than plant introductions. In a separate experiment, 25 lines previously considered resistant were evaluated in the field with infested cowpea crop debris and susceptible rows as sources of inocula. Only 3 lines $(39, \mathrm{KVu} / 175$, and 46) maintained their high levels of resistance to Sphaceloma scab. Five cowpea lines were subsequently diallel-crossed, and parents and F2 were evaluated in the field to determine the nature of inheritance of resistance to Sphaceloma scab. The majority of the crosses between the resistant and susceptible lines showed intermediate reaction to scab, and high variation was obtained due to genotype and combining abilities. Partitioning of the variance into components due to general and specific combining ability revealed that additive genetic variation constituted the major portion of the total genetic variance for resistance to scab in cowpea.

Additional keywords: Sphaceloma sp., Vigna unguiculata

Cowpea, Vigna unguiculata L. Walp., is a heat- and drought-resistant crop grown widely in the semi-arid tropics. Seed yields average only 100 to $300 \mathrm{~kg} / \mathrm{ha}$, largely due to the effects of insects and diseases (20). Among the many diseases of cowpea, scab caused by Sphaceloma sp. is particularly destructive and affects all aboveground parts of the plant $(2,3,5)$. With severe infection, pods are heavily spotted, curled, and transformed into "mummies" containing no seed $(5,6,9-11,19)$. Infected seed and infested crop debris are primary sources of inocula for scab (2).

Limited literature is available on control measures for scab, but the use of host resistance has been suggested $(2,9,10)$. However, efficient use of the sources of resistance requires an understanding of genetic variability in the germ plasm available for

Corresponding author: E. Adipala

E-mail: acss@starcom.co.ug

The first author was supported by a grant from USAID through the Faculty of Agriculture and Forestry, Makerere University. Supplementary funding was provided by the Makerere University Cowpea Improvement Project, financed by The Rockefeller Foundation Forum Grant RF 93040 $\# 13$.

Accepted for publication 29 June 1997.

Publication no. D-1997-1006-01R

(C) 1997 The American Phytopathological Society selection (10). Reaction of cowpea lines to Sphaceloma sp. ranges from resistant to susceptible (2). There was considerable variation in cowpea susceptibility to scab for the 80 lines tested at the Makerere University farm, Uganda, but no line was completely free of scab infection (10). On the other hand, host reaction is measured by the ability of the host to reduce the growth, reproduction, and/or disease production abilities of the pathogen (13). Previously, resistance to scab in Uganda was evaluated on some cowpea lines based on foliar infection $(9,10)$. However, the direct effects of scab infection on yield are reduction in pod number and size, seed yield, and seed viability.

The high costs of pesticides, the lack of the necessary knowledge to use pesticides safely and effectively, pesticide residues, and the development of pest resistance to pesticides make breeding for plant resistance to diseases more important in this era $(2,19)$. Results of inheritance studies have been published for some important fungal diseases of cowpea such as anthracnose (Colletotrichum lindemuthianum Sacc. and Magnus; 2,19), Cercospora leaf spot (Cercospora cruenta Ell. and Mart. and $C$. canescens; 2,6), Fusarium wilt (Fusarium oxysporum Schlechtend:Fr. f. sp. tracheiphilum (E.F. Sm.) W.C. Snyder \& H.N. Hans.; 6), powdery mildew (Erysiphe polygoni DC.), brown rust (Uromyces appendiculatus (Pers.:Pers.) Unger), stem rot
(Pythium aphanidermatum (Edson) Fitzp.), and target leaf spot (Corynespora cassiicola (Berk. \& M.A. Curtis) C.T. Wei; $1,2,11,12,19)$. Despite the progress in development of resistant cultivars, very few cowpea lines resistant to scab have been identified (10), yet cowpea scab and other diseases can cause yield losses of up to $60 \%(10,18,19)$. The most effective and economical scab control measure is to use resistant cowpea cultivars (19), but little is known about the genetics of resistance to Sphaceloma scab.

The objectives of this study were to evaluate scab infection on both pod and foliar bases and to determine the relationship between the two sites of infections on 75 cowpea lines. We also screened 25 cowpea lines that had shown some levels of resistance to Sphaceloma sp. under natural disease epidemics, and elucidated the nature of resistance to scab in cowpea.

\section{MATERIALS AND METHODS}

Identification of sources of resistance to scab. The experiment was conducted at the Makerere University Agricultural Research Institute (MUARIK), Kabanyolo, Uganda, in a field previously planted to maize. The 75 cowpea lines (27 lines from the International Institute of Tropical Agriculture (IITA), 27 lines from Kenya and Tanzania, and 21 local collections from Uganda) were planted in a randomized complete block design replicated three times, during the second rains of 1993 and the first rains of 1994, on 18 September and 14 April, respectively. Two seeds/hill were sown and later thinned to one plant/hill. The cowpeas were planted at a spacing of 75 by $30 \mathrm{~cm}$ in 80 by $5 \mathrm{~m}$ plots. Ten days before the main experiment, a susceptible line IT83S-872 was planted across and along the blocks to act as a source of inoculum.

For the second experiment, 25 cowpea lines previously rated resistant/moderately resistant under natural disease pressure (9) were planted on 14 April and 16 October 1994, and 21 March 1995. Plots, 20 by 5 $\mathrm{m}$, were bordered with a scab-susceptible cowpea line planted 10 days prior to the main crop. Fifteen days after the planting, scab-infested cowpea debris were introduced along the rows to ensure high disease levels. All experiments were laid out in randomized complete blocks replicated three times. Rows, $4.5 \mathrm{~m}$ long, were spaced $75 \mathrm{~cm}$ apart with $30 \mathrm{~cm}$ between seeds. There was no fertilizer application, 
but dimethoate, (O-o-dimethyl S-methylcarbomoylmethyl phosphorodithioate, 200 $\mathrm{g}$ a.i./ha) and chlorpyrifos (Dursban; O-odiethyl 0-3, 5, 6, trichloro-2-pyridyl 5G, $600 \mathrm{~g}$ a.i./ha) were applied to control insect pests, especially aphids (Aphis craccivora Koch), thrips (Megalurothrips sjostedti Trybom), pod-sucking bugs (especially Anoplocnemis curvipes (Fabricius)), and pod borers (Maruca testulalis Geyer).

Disease rating. In each plot of the 75 cowpea lines, five plants were arbitrarily selected and tagged. Each tagged plant was rated for disease severity on a scale of 1 to 5, as follows: $1=0 \%$ infection (no visible symptoms on either foliage or pods); $2=$ less than $10 \%$ scab infection (scattered lesions on either foliage or pods); $3=10$ to $20 \%$ infection (extensive spotting of young stems and branches or on the pods); $4=20$ to $50 \%$ infection (stem lesions coalescing, covering half the plants or the pods); and 5 $=50 \%$ or greater infection (foliage severely damaged or pods transformed into mummies containing virtually no seeds). On this scale, lines with ratings of less than 2,2 to 3 , and 3 or greater were considered resistant, moderately resistant, and susceptible, respectively.

For the first experiment, disease severity was recorded five times at 7-day intervals beginning 45 days after planting (DAP) for foliar infection, and 80 DAP for pod infection. Because of low disease intensity during the second rains of 1993, data for only one season were considered for the 75 cowpea lines. For the second experiment, disease rating commenced $65 \mathrm{DAP}$ at 7 to 8 days intervals for a total of six times. Harvesting was done on 24 July 1994, and 13 January and 29 July 1995 . The 5 plants on which disease was assessed were harvested separately for each line, and the total dry weight of seeds recorded. Average yield ( $\mathrm{kg} / \mathrm{ha}$ ) for each cowpea line was then computed.

The mean disease ratings for the 5 plants in each row were calculated and used to compute area under a disease progress curve (AUDPC; 4). The last assessments were taken as final severity and disease was assumed to be at full development. The linearized logistic model was used to obtain the apparent infection rate $(r ; 4,21)$.

Table 1. Levels of resistance and origin of cowpea lines evaluated in a diallel mating design at Kabanyolo, Uganda

\begin{tabular}{lcr}
\hline Line & Level of resistance $^{\mathbf{y}}$ & Origin $^{-}$ \\
\hline 39 & Resistant & Uganda \\
46 & Resistant & Uganda \\
IV 1658 & Intermediate & Uganda \\
ITA-15 & Susceptible & IITA \\
IT83S-872 & Susceptible & IITA \\
\hline
\end{tabular}

${ }^{y}$ Levels of resistance were based on disease rating scale in field screening tests under natural and artificial disease pressure.

${ }^{\mathrm{z}}$ International Institute of Tropical Agriculture, Ibadan, Nigeria.
Final severities, AUDPC, and slope $(r)$ of the regression equations were subjected to analysis of variance (ANOVA). When $F$ values indicated significance $(P=0.05)$, Fisher's protected least significant difference (LSD) was calculated. Relationships between the disease indices and yield were inspected by correlation analysis.

Inheritance of resistance to scab in cowpea. Following extensive screening of cowpea lines, 5 cowpea lines (Table 1) were selected based on their levels of resistance to scab, and were crossed in a diallel mating scheme. The objective was to elucidate the inheritance of resistance to scab in cowpea. Hand-pollination was done in a greenhouse under controlled environmental conditions. Flowers were emasculated before pollen shedding, pollinated, and covered with transparent polyethylene film to prevent contamination from stray pollen. The film was removed once pod formation was initiated. Mature pods were harvested separately from each plant and the seeds planted in a screen-house. Parents (selfers) and 10 F2 from the diallel experiment were planted in the field on 15 November 1994. A randomized complete block design was used with three replications. Each (parent and F2) cowpea line was grown in a two-row plot, $4.5 \mathrm{~m}$ long, at a spacing of $75 \mathrm{~cm}$ between rows and 30 $\mathrm{cm}$ between plants. Dimethoate $(200 \mathrm{~g}$ a.i./ha) and chlorpyrifos (600 g a.i./ha) were applied to control insect pests. Weeding was done twice during the growth period. Two weeks after emergence of the seedlings, scab-infested cowpea residue was introduced in the experimental plots along the rows. The infested residue provided initial source of scab inoculum, while the susceptible line ensured further multiplication of the inoculum so that there was no disease escape.

Disease analysis. From each of the two plot rows, 5 plants were arbitrarily selected and tagged. Disease severity was scored on each tagged plant on a 1 to 5 scale as described in the section on disease rating. Ratings were conducted three times at 54, 61 , and 73 DAP. Plot means of the third rating were considered full disease development.

Mean values of the 10 randomly selected plants were used for statistical analyses. Mean disease severity values were used to calculate AUDPC (4). The AUDPC and final severity were subjected to ANOVA, and LSD were calculated.

Cultivars used as parents were considered to be fixed variables; hence, inferences from the analysis were limited to sets of crosses, and Griffing's (8) Method I (fixed effects) was used to determine combining ability for scab resistance.

\section{RESULTS}

Identifications of sources of resistance to scab. A continuum of cowpea reactions to foliar infection was observed (Table 2). Final severity ratings ranged from 1.25 to 4.63, and AUDPC ranged from 1.17 to 4.15 , with a mean value of 2.21 . Lines rated resistant included: 46, Majije Ex2, IT82D-3850-1, KATUMANI 80, 17, 39, IT82D-716, and $\mathrm{KVu} / 175$. Line 46 was the most resistant, whereas lines IT83S-872 and IT86D-535 were the most susceptible.

All cowpea lines had infected pods. Final severity on pods ranged from 1.30 to 4.25, and AUDPC ranged from 1.16 to 4.20. Of the lines rated resistant, line 39

Table 2. Mean values of final severity (FS), area under disease progress curve (AUDPC), and apparent infection rate (AIR) of the linearized logistic increase in both whole plant and pod infection by Sphaceloma scab on 17 selected cowpea lines among the 75 grown at Kabanyolo, Uganda, during the first rains of 1994

\begin{tabular}{lccccccc}
\hline & \multicolumn{3}{c}{ Whole plant infection } & & \multicolumn{3}{c}{ Pod infection } \\
\cline { 2 - 3 } \cline { 7 - 8 } Line & FS $^{\mathbf{y}}$ & AUDPC & AIR & & FS & AUDPC & AIR \\
\hline 39 & $1.75^{z}$ & 1.45 & 0.04 & & 1.30 & 1.16 & 0.02 \\
KVu/175 & 1.88 & 1.54 & 0.03 & & 1.83 & 1.66 & 0.04 \\
IV1658 & 2.54 & 2.32 & 0.04 & & 1.30 & 1.24 & 0.28 \\
VITA 6 & 3.75 & 3.02 & 0.07 & & 1.42 & 1.27 & 0.02 \\
42 (7) & 2.75 & 2.16 & 0.06 & & 1.55 & 1.41 & 0.01 \\
46 & 1.25 & 1.17 & 0.02 & & 1.90 & 1.60 & 0.04 \\
MAJIJE & 1.25 & 1.18 & 0.03 & & 1.72 & 1.57 & 0.02 \\
KATUMANI & 1.75 & 1.58 & 0.03 & & 2.40 & 2.22 & 0.02 \\
IT82E-16 & 1.88 & 1.54 & 0.03 & & 2.15 & 1.28 & 0.70 \\
12* & 4.00 & 3.41 & 0.06 & & 2.35 & 2.31 & 0.02 \\
KVu-530 & 2.38 & 2.15 & 0.03 & & 2.93 & 2.58 & 0.03 \\
TVx-3236 & 2.50 & 2.35 & 0.04 & & 2.84 & 2.27 & 0.05 \\
IT84S-2125 & 2.38 & 2.10 & 0.02 & & 2.55 & 2.38 & 0.02 \\
IT84S-2246 & 2.88 & 2.22 & 0.06 & & 2.30 & 2.14 & 0.03 \\
84 & 4.38 & 3.82 & 0.08 & & 2.20 & 2.04 & 0.02 \\
IT86D-535 & 4.38 & 4.12 & 0.06 & & 3.66 & 3.60 & 0.04 \\
IT83S-872 & 4.63 & 4.15 & 0.10 & & 4.25 & 4.20 & 0.05 \\
LSD (0.05) & 1.27 & 1.20 & 0.04 & & 1.55 & 1.45 & 0.08 \\
CV (\%) & 31.48 & 34.48 & 44.52 & & 33.43 & 32.42 & 40.22 \\
\hline
\end{tabular}

${ }^{\mathrm{y}}$ Levels of resistance were based on disease rating scale: $1=0 \%$ infection; $2=<10 \%$ infection; $3=10$ to $20 \%$ infection; $4=20$ to $50 \%$ infection; $5=\geq 50 \%$ infection.

${ }^{\mathrm{z}}$ Data are means of three replications. 
was the most resistant, followed by IV 1658 (Table 2).

For the moderately resistant/susceptible group, IT82D-699, 84, SLA 59, and VITA 6 were the least affected. Of the 75 cowpea lines studied, 24 were rated resistant, of which 7 lines were from IITA, 6 from Kenya/Tanzania, and 11 from Uganda. Forty lines were rated moderately resistant to susceptible. These included 12 lines from IITA, 19 from Kenya/Tanzania, and 9 from Uganda. Eleven lines were rated very susceptible; of these, 8 were from IITA, 2 were from Kenya/Tanzania, and only one from Uganda.

When all 75 lines were compared, cowpea lines from Uganda were most resistant, whereas lines from IITA were the most susceptible. Although most cowpea lines showed similar trends for both foliar and pod infections, this was not the case for lines such as 12, VITA 6, 42, KATUMANI 80 , and 84 , which were either resistant or susceptible to foliar or pod infection, but not both. Overall, evaluation of pod and foliar infection showed that lines 39, 46, and MAJIJE were the most resistant (Table 2). IT83S-872 was the most susceptible. Correlation based on foliar infection showed a strong relationship between AUDPC and final severity and apparent infection rate $(P \leq 0.001 ; r=0.85$ and 0.59 , respectively).

Disease severity ratings among the 25 cowpea lines previously identified as resistant showed little variation during the first rains of 1994, but higher disease ratings were recorded during the second season of 1994 and first rains of 1995 (Table 3). Based on AUDPC, disease severity ranged from 1.11 to $2.51 ; 1.59$ to 3.29 during the first and second rainy seasons of 1994, and 1.07 to 3.67 during the first rains of 1995. During the first rainy season of 1994, 15 lines were considered resistant, 7 cowpea lines susceptible, and the rest moderately resistant; only 3 lines were rated resistant during the second rainy season of 1994 and the first rainy season of 1995. Overall, cowpea lines with disease ratings below 2.00 were classified as resistant; these included 39, 42, 46, $\mathrm{KVu} / 175$, IT85-3850-1, ERA 7, 17, IT82D-522-1, and IT87S-1321 for the second rainy season of 1994 , and $\mathrm{KVu} / 175$, 39, IT87S-1321, and IT82D-522 for the first rains of 1995. The most resistant lines for both seasons were $39, \mathrm{KVu} / 175$, IT82D-1321, and 46.

Based on final severity index, lines with ratings above 3.0 were considered susceptible. Only 1 line (KVu454) was rated susceptible during the first rainy season of 1994, whereas 7 lines were considered susceptible during the second rainy season of 1994 (Table 3). Disease level was higher during the first season of 1995, but lines IT82D-522, $\mathrm{KVu} / 175$, and 39 maintained their resistance (Table 3 ).

The average yield of cowpea during the first rainy season of 1994 ranged from 178 to $1,563 \mathrm{~kg} / \mathrm{ha}$, with a mean value of 619 .
IV1075 and TVx3236 had the lowest yield, while TVu465 and IV 1658 had the highest yield (Table 4). Average yields during the second rainy season of 1994 ranged from 139 to $1,058 \mathrm{~kg} / \mathrm{ha}$ (Table 4). For the first rainy season of 1995 , line 46 (highly resistant to scab) had the highest mean yield (980 kg/ha), whereas SLA 59 had the lowest yields (128 kg/ha; Table 4). For the susceptible genotypes, disease severity (AUDPC) was highly correlated with yield during the second season of 1994 ( $r=$ $-0.43, P=0.01)$, and second tests of 1995 ( $r=-0.56, P=0.01$ ), but not correlated with yield for all the genotypes during the first season of 1994 trial $(r=-0.08, P=$ 0.86).

Inheritance of resistance to Sphaceloma scab. Both the parents and crosses differed significantly $(P \leq 0.01)$ in the mean disease ratings (Table 5). Line 39 was the most resistant while IT83S-872 was the most susceptible. Line 39 crosses also showed significantly lower disease ratings (Table 5).

Combining abilities were partitioned into general and specific combining abilities (GCA, SCA). Both the GCA and SCA effects were highly significant (Table 6). However, for final severity the GCA mean square (21.5334) was 6.4 times larger than the SCA mean squares (3.3430), and for AUDPC it was 6.6 times larger than the SCA mean squares (Table 6). Only negative values of GCA indicated contribution towards scab resistance (Table 7). The best

Table 3. Mean values of final severity (FS) and area under disease progress curve (AUDPC) of Sphaceloma infection on 25 cowpea lines originally considered to be resistant to scab grown at Kabanyolo in 1994 and 1995.

\begin{tabular}{|c|c|c|c|c|c|c|c|c|c|}
\hline \multirow[b]{2}{*}{ Line } & \multicolumn{3}{|c|}{ March-June 1994} & \multicolumn{3}{|c|}{ September-December 1994} & \multicolumn{3}{|c|}{ March-June 1995} \\
\hline & FS $^{y}$ & AUDPC & $\mathbf{H R}^{\mathbf{z}}$ & FS & AUDPC & HR & FS & AUDPC & HR \\
\hline KVu 454 & 3.07 & $2.51 \mathrm{MR}$ & & 2.87 & $2.51 \mathrm{MR}$ & & 3.20 & $3.06 \mathrm{~S}$ & \\
\hline TVx3 236 & 2.87 & 2.51 & MR & 3.08 & 2.80 & MR & 4.05 & 3.67 & $\mathrm{~S}$ \\
\hline 12 & 2.87 & 2.74 & MR & 3.00 & 3.20 & $\mathrm{~S}$ & 3.17 & 3.04 & $\mathrm{~S}$ \\
\hline TVu-465 & 2.47 & 2.36 & MR & 3.40 & 3.20 & $\mathrm{~S}$ & 3.43 & 3.13 & $\mathrm{~S}$ \\
\hline SLA 59 & 2.47 & 2.26 & MR & 2.53 & 2.54 & MR & 2.43 & 2.36 & MR \\
\hline IT83S-639 & 2.60 & 2.25 & MR & 3.33 & 3.14 & S & 3.63 & 3.39 & $\mathrm{~S}$ \\
\hline IT83D-422 & 2.73 & 2.24 & MR & 3.40 & 3.08 & $\mathrm{~S}$ & 3.43 & 3.20 & $\mathrm{~S}$ \\
\hline IT84D-448 & 2.26 & 2.11 & MR & 2.60 & 2.51 & MR & 2.67 & 2.59 & MR \\
\hline IT84S-2125 & 2.40 & 2.21 & MR & 2.87 & 3.26 & $\mathrm{~S}$ & 2.93 & 2.73 & MR \\
\hline 42 & 1.80 & 1.78 & $\mathrm{R}$ & 3.27 & 3.05 & $\mathrm{~S}$ & 3.00 & 2.94 & $\mathrm{~S}$ \\
\hline 82 & 2.27 & 1.97 & $\mathrm{R}$ & 2.53 & 2.78 & MR & 2.60 & 2.37 & MR \\
\hline N1593 & 2.20 & 1.93 & $\mathrm{R}$ & 3.07 & 2.88 & MR & 3.03 & 2.97 & $\mathrm{~S}$ \\
\hline IV1658 & 2.07 & 1.93 & $\mathrm{R}$ & 2.93 & 2.64 & MR & 3.13 & 2.97 & $\mathrm{~S}$ \\
\hline IT82D-634 & 2.20 & 1.87 & $\mathrm{R}$ & 2.33 & 2.46 & MR & 2.97 & 2.84 & MR \\
\hline KVu 530 & 2.27 & 1.84 & $\mathrm{R}$ & 2.73 & 2.29 & MR & 2.37 & 2.14 & MR \\
\hline IT87S-1321 & 2.07 & 1.55 & $\mathrm{R}$ & 2.13 & 1.81 & $\mathrm{R}$ & 2.67 & 2.52 & MR \\
\hline IT82D-522 & 1.93 & 1.82 & $\mathrm{R}$ & 2.70 & 2.59 & MR & 1.83 & 1.75 & $\mathrm{R}$ \\
\hline ERA 7 & 1.93 & 1.76 & $\mathrm{R}$ & 2.07 & 2.22 & MR & 2.93 & 2.73 & MR \\
\hline IT85D-3850 & 1.93 & 1.65 & $\mathrm{R}$ & 3.53 & 3.29 & $\mathrm{~S}$ & 3.70 & 3.47 & $\mathrm{~S}$ \\
\hline KATUMANI 80 & 2.27 & 2.09 & MR & 2.93 & 2.88 & MR & 3.27 & 3.11 & $\mathrm{~S}$ \\
\hline 17 & 1.93 & 1.62 & $\mathrm{R}$ & 2.60 & 2.50 & MR & 2.43 & 2.30 & MR \\
\hline IV1075 & 1.93 & 1.62 & $\mathrm{R}$ & 2.47 & 2.38 & MR & 3.17 & 2.97 & $\mathrm{~S}$ \\
\hline $\mathrm{KVu} / 175$ & 1.93 & 1.54 & $\mathrm{R}$ & 2.00 & 1.59 & $\mathrm{R}$ & 1.70 & 1.52 & $\mathrm{R}$ \\
\hline 46 & 1.67 & 1.43 & $\mathrm{R}$ & 2.13 & 2.01 & MR & 2.22 & 2.10 & MR \\
\hline 39 & 1.13 & 1.11 & $\mathrm{R}$ & 1.11 & 1.08 & $\mathrm{R}$ & 1.13 & 1.07 & $\mathrm{R}$ \\
\hline $\operatorname{LSD}(0.05)$ & 0.96 & 0.84 & & 0.70 & 0.52 & & 0.75 & 0.63 & \\
\hline $\mathrm{CV}(\%)$ & 29.01 & 27.80 & & 16.10 & 12.46 & & 14.35 & 11.85 & \\
\hline
\end{tabular}

${ }^{\mathrm{y}}$ Levels of resistance were based on disease rating scale: $1=0 \%$ infection; $2=<10 \%$ infection; $3=10$ to $20 \%$ infection; $4=20$ to $50 \%$ infection; $5=\geq$ $50 \%$ infection.

${ }^{\mathrm{z}}$ Host reactions: $\mathrm{R}=$ resistant, $\mathrm{MR}=$ moderately resistant, and $\mathrm{S}=$ susceptible. 
Table 4. Mean yield (kg/ha) of 25 cowpea lines grown at Kabanyolo, Uganda, in 1994 and 1995

\begin{tabular}{lccc}
\hline Line & June $\mathbf{1 9 9 4}$ & December $\mathbf{1 9 9 4}$ & June 1995 \\
\hline KVu 454 & $821.40^{2}$ & 485.86 & 534.55 \\
TVx3 236 & 178.35 & 371.83 & 158.92 \\
12 & 473.08 & 363.19 & 245.96 \\
TVu 465 & 1563.88 & 235.50 & 598.25 \\
SLA 59 & 466.20 & 139.23 & 128.20 \\
IT83S-639 & 555.00 & 301.81 & 235.68 \\
IT83D-422 & 834.92 & 429.60 & 540.45 \\
IT84D-448 & 856.92 & 269.00 & 458.92 \\
IT84S-2125 & 251.30 & 404.40 & 565.32 \\
KATUMANI 80 & 552.80 & 604.96 & 598.36 \\
82 & 568.32 & 476.40 & 485.20 \\
N1593 & 444.00 & 413.87 & 458.35 \\
IV 1658 & 1132.20 & 528.26 & 854.60 \\
IT84D-634 & 856.92 & 433.16 & 542.37 \\
KVu 530 & 621.60 & 511.94 & 729.30 \\
IT87S-1321 & 333.15 & 494.75 & 440.40 \\
IT82D-522 & 850.41 & 444.40 & 750.60 \\
42(7) & 452.89 & 288.00 & 355.40 \\
ERA 7 & 381.54 & 717.26 & 550.75 \\
IT85D-3850 & 212.01 & 583.42 & 354.20 \\
17 & 397.08 & 531.19 & 659.55 \\
IV1075 & 178.34 & 440.40 & 355.60 \\
KVu/175 & 388.60 & 426.94 & 364.45 \\
46 & 894.71 & 1058.25 & 980.50 \\
39 & 728.16 & 766.46 & 702.54 \\
LSD (0.05) & 258.23 & 31.26 & 234.53 \\
CV (\%) & 48.84 & & 42.63 \\
\hline 2 Da & & & \\
\hline
\end{tabular}

${ }^{\mathrm{z}}$ Data are means of three replicates.

Table 5. Levels of Sphaceloma scab on parental lines and crosses of cowpea at Kabanyolo, Uganda, during the second rains of 1994

\begin{tabular}{lcc}
\hline Genotype & Final severity & \\
\hline Parents & & AUDPC $^{\mathbf{z}}$ \\
46 & 2.00 & 1.73 \\
IT83S-872 & 3.95 & 3.67 \\
ITA 15 & 3.35 & 3.14 \\
IV1658 & 2.35 & 2.08 \\
39 & 1.00 & 1.07 \\
Crosses (F2) & & \\
$46 \times$ IT83S-872 & 2.60 & 2.33 \\
$46 \times$ ITA-15 & 1.80 & 1.53 \\
$46 \times$ IV 1658 & 1.30 & 1.27 \\
$46 \times 39$ & 1.20 & 1.15 \\
IT83S-872 $\times$ ITA-15 & 4.05 & 3.52 \\
IT83S-872 $\times$ IV1658 & 3.01 & 2.71 \\
IT83S-872 $\times 39$ & 2.20 & 1.90 \\
ITA-15 $\times$ IV1658 & 1.70 & 1.66 \\
ITA-15 $\times 39$ & 2.05 & 1.91 \\
IV1658 $\times 39$ & 1.40 & 1.31 \\
LSD $(0.05)$ & 0.48 & 0.47 \\
CV $(\%)$ & 15.77 & 15.69
\end{tabular}

y Disease rating scale: $1=0 \%$ infection; $2=<10 \%$ infection; $3=10$ to $20 \%$ infection; $4=20$ to $50 \%$ infection; $5=\geq 50 \%$ infection

${ }^{\mathrm{z}}$ Area under disease progress curve.

general combiners for scab resistance were lines 39 and 46, which had the highest negative GCA. Lines IT83S-872 and ITA15 , which were among the susceptible lines, had the largest positive GCA for both final severity and AUDPC (Table 7).

\section{DISCUSSION}

Reaction of cowpea lines to scab varied from resistant to susceptible, and all the lines showed symptoms of the disease. Similar observations were obtained earlier in Uganda $(9,10)$ and elsewhere (2). All the aboveground parts of susceptible plants were affected, which is typical of scab spreader lines encouraged disease development, as was evidenced by the high disease scores on the susceptible lines such as IT83S-872 compared with the resistant lines such as 39. Similar findings have been reported earlier $(2,5)$. In our study, cowpea lines IT85D-3850, TVu465, 12, IT83D-422, IT84D-448, IT83S-639, 42, and KATUMANI 80, previously considered resistant (9), were rated susceptible. This difference could have been brought about by introduction of infested crop debris and the susceptible line that provided higher levels of inocula. In contrast, some lines maintained their levels of resistance, including 46, 39, IT82D-522, and $\mathrm{KVu} / 175$, with disease ratings of less than 2.2 on our rating scale.

One of the major goals of many legume improvement programs has been to breed for insect and disease resistance $(11,12,19,20)$. In our study, sources of resistance to Sphaceloma scab that can be used in breeding programs to develop cowpea lines resistant to scab were identified. The use of highly infested residue as source of inoculum for Sphaceloma sp. holds promise for screening cowpea germ plasm for resistance to scab, since it is very difficult to culture this fungus.

Significant variation among crosses was due to GCA and SCA; this suggests the existence of genetic diversity among individual lines. Although it was apparent that both GCA and SCA were important as sources of variation in resistance to scab, total variation among these crosses was attributed more to GCA differences existing among the parents than to SCA effects. According to Gevers and Lake (7), high positive GCA indicates low gene frequency. This was exhibited by lines IT83S872 and ITA-15, which were rated susceptible and therefore poor general combiners. Furthermore, SCA effects reflect the deviation of a cross from its expected performance (based on GCA effects; 14,15). Therefore, the significant SCA effects in crosses could be attributed to dominance and epistatic effects. The large GCA obtained indicated that additive inheritance was of major importance (8). Lines 39 and 46 had the highest negative GCA, and therefore, should possess a high gene frequency for scab resistance. These resistant sources would make good parents for improvement of cowpea resistance to scab.

Generally, the crosses between resistant and susceptible lines showed intermediate reactions to scab. This indicated the presence of partial resistance (based on many genes) which was also reported by Allen et al. (3). Furthermore, the high values of GCA effect indicated that the resistance to scab was under additive gene action, and such resistance is commonly referred to as non-race-specific (21). This is contrary to earlier findings which suggested monogenic resistance to scab (1). In fact the significant SCA effects suggest the pres- 
Table 6. Analysis of variance for combining ability for resistance to cowpea scab in diallel crosses grown in Kabanyolo, Uganda, during the second rains of 1994

\begin{tabular}{lccc}
\hline & & \multicolumn{2}{c}{ Mean squares } \\
\cline { 3 - 4 } Sources of variation & df & Final severity & AUDPC $^{\mathbf{v}}$ \\
\hline Genotype $^{\mathrm{w}}$ & 14 & $3.765^{* * \mathrm{x}}$ & $2.661^{* *}$ \\
GCA $^{\mathrm{y}}$ & 4 & $21.533^{* *}$ & $15.049^{* *}$ \\
SCA $^{\mathrm{z}}$ & 10 & $3.343^{* *}$ & $2.294^{* *}$ \\
Error & 14 & 0.077 & 0.091 \\
\hline
\end{tabular}

${ }^{\mathrm{v}}$ Area under disease progress curve.

${ }^{\mathrm{w}}$ Genotype of the parents and the crosses.

x ** = significant at $P=0.01$.

${ }^{y}$ General combining ability of the parents.

${ }^{\mathrm{z}}$ Specific combining ability of the crosses.

ence of dominance or major gene action, but these effects were smaller than the GCA effects. It is, therefore, probable that this resistance had small race-specific effects. Similar findings were observed on barley leaf rust $(16,17)$. The highly significant negative GCA effects for lines 39 and 46 indicate that these lines would be good choices as parents for transferring genes for resistance to scab.

\section{ACKNOWLEDGMENTS}

We thank the International Institute of Tropical Agriculture (IITA), Ibadan, Nigeria, and D. A. Florini, for their support; and $\mathrm{H}$. Ojulong for technical assistance.

\section{LITERATURE CITED}

1. Abadassi, J. 1984. Inheritance of resistance to brown blotch, Septoria leaf spot and scab diseases in cowpea. Abomey-Calavi, Benin, Universite Nationale du Benin.

2. Allen, D. J. 1983. The Pathology of Tropical Food Legumes. Disease Resistance in Crop Improvement. Wiley-Interscience, New York.

3. Allen, D. J., Emechebe, A. M., and Ndimande, B. 1981. Identification of resistance to diseases of the African savannas. Trop. Agric. (Trinidad) 58: 267-274.

4. Campbell, C. L., and Madden, L. V. 1990. Introduction to Plant Disease Epidemiology. John Wiley and Sons, New York.

5. Emechebe, A. M. 1980. Scab disease of cow-
Table 7. Estimates of general combining ability (GCA) effects for final severity and area under disease progress curve (AUDPC) of scab on three resistant and two susceptible cowpea lines

\begin{tabular}{lcc}
\hline Parent & Final severity & AUDPC $^{\mathbf{y}}$ \\
\hline 46 & $-0.380^{* * \mathrm{z}}$ & $-0.363^{* *}$ \\
IT83S-872 & $0.899^{* *}$ & $0.752^{* *}$ \\
ITA-15 & $0.299^{* *}$ & $0.252^{*}$ \\
IV 1658 & -0.123 & -0.085 \\
39 & $-0.694^{* *}$ & $-0.555^{* *}$ \\
\hline
\end{tabular}

${ }^{\mathrm{y}}$ Area under disease progress curve.

$\mathrm{z} *$ and $* *=$ significant at the 0.05 and 0.01 levels of probability, respectively.

Plant Dis. 75:1094-1097.

pea (Vigna unguiculata) caused by Sphaceloma a species of fungus. Ann. of Appl. Biol. 96: 11-16.

6. Emechebe, A. M., and Shoyinka, S. A. 1985. Fungal and bacterial diseases of cowpeas in Africa. Pages 173-192 in: Cowpea Research, Production and Utilization. S. R. Singh, and K. O. Rachie, eds. Wiley-Interscience, New York.

7. Gevers, H. O., and Lake, J. K. 1994. Diallel cross analysis of resistance to gray leaf spot in maize. Plant Dis. 78:379-382.

8. Griffing, B. 1956. Concepts of general and specific combining abilities in relation to diallel crossing systems. Aust. J. Biol. Sci. 9:463-493.

9. Iceduna, L. C. 1993. Selection for Resistance and Fungicidal Control of Cowpea scab (Sphaceloma sp.) in Uganda. M. Sc. Thesis, Makerere University, Kampala.

10. Iceduna, L. C., Adipala, E., and OgengaLatigo, M. W. 1994. Evaluation of 80 cowpea lines for resistance to scab, Sphaceloma sp. Afr. Crop Sci. J. 2:207-214

11. International Institute of Tropical Agriculture (IITA). 1984. Grain Legume Improvement Bulletin No. 29. International Institute of Tropical Agriculture. Ibadan, Nigeria.

12. International Institute of Tropical Agriculture (IITA). 1990. Grain Legume Improvement. Annual Report and Research Highlights of 1989. International Institute of Tropical Agriculture, Ibadan, Nigeria.

13. Meyer, A. C., Pataky, J. K., and Juvik, J. A. 1991. Partial resistance to northern leaf blight and Stewart's wilt in sweet corn germ plasm.
14. Olunju, A. G., Bramel-Cox, P. J., and Harvey, T. L. 1990. Diallel analysis of resistance in sorghum to greenbug biotype: Antibiosis and tolerance. Crop Sci. 30:1055-1059.

15. Olurunju, P. E., Kuhn, C. W., Misari, S. M., and Ansa, O. A. 1992. Inheritance of resistance in peanut to mixed infection of groundnut rosette assistor virus and or single infection of (GRV). Plant Dis. 76:95-100.

16. Parlevliet, J. E. 1978. Further evidence of polygenic inheritance of partial resistance in barley to leaf rust, Puccinia hordei. Euphytica 27: 369-379.

17. Parlevliet, J. E., and Zadoks, J. C. 1977. The integrated concept of disease resistance; a new view including horizontal and vertical resistance in plants. Euphytica 26:5-21.

18. Rusoke, D., and Rubaihayo, P. 1994. The influence of some crop protection management practices on yield stability of cowpeas. Afr. Crop Sci. J. 2:43-48

19. Singh, S. R., and Allen, D. J. 1979. Cowpea Pests and Diseases. International Institute of Tropical Agriculture, Ibadan, Nigeria.

20. Singh, B. B., and Singh, S. R. 1990. Breeding for bruchid resistance in cowpea. Pages 212228 in Bruchids and Legumes: Economics, Ecology, and Co-evolution. K. Fujii, A. M. R. Gatehouse, C. D. Jonson, R. Mitchel, and Yoshida, eds. Kluwer Academic Publishers, Dordrecht, Netherlands.

21. Van der Plank, J. E. 1963. Plant Diseases. Epidemics and Control. Academic Press, New York 